\title{
The everyday life of Papuan civil servants 1950-1990
}

\author{
Leontine Visser
}

This book started as an oral history of the governance of Netherlands New Guinea from about 1950 to 1962, as lived and experienced by the indigenous Papuan civil servants at the time. It is based on a series of interview sessions held during 1999 and 2000 in Jayapura and Biak. Yet, the book is more than a series of personal accounts of a unique period in the social-cultural, economic, and political history of the geographical space that today forms the two Indonesian provinces of Papua and West Papua. Particularly the second round of interviews took place in a highly politicized environment ${ }^{1}$ which stimulated the former civil servants to reflect on their lives and actions as members of the ruling elite of a developing nation. This unplanned contextualization of their accounts added the important extra dimension of subjective comparison of their functioning in the Dutch development administration of the 1950's until 1962 and the Indonesian government administration of Soeharto's New Order. The Papuan civil servants ${ }^{2}$ were still in their late teens when they took up major responsibilities in the development of New Guinea, first under supervision of the Dutch, but by the end of the decade, often also as their colleagues. After 1962, they continued to serve their people as

\footnotetext{
1 The year 2000 was particularly tense in Papua. After a meeting with President Habibie, Papuans started gathering in a mass movement. During two grand meetings an organization was added to the movement. The first of these meetings was held in Sentani, the Great Conference (Musyawarah Besar) in February 2000. The second was held in Jayapura, namely the 2nd Papuan Peoples' Congress (Kongres Papua) in May 2000, calling for a rectification of the history of the struggle of West Irian (meluruskan sejarah perjuangan Irian Barat) (see also Chauvel 2008). Reactions from Jakarta were violent; bloody incidents happened, culminating in the killing of Theys Eluay in November 2001.

2 For two reasons we prefer to speak of civil servants, rather than of government officials, let alone colonial officials (Chauvel 2008). Firstly, the interviewees themselves stressed their position as a 'servant of the people' (hamba rakyat) which of course is a true translation of the Dutch moral code of a dienaar des volks. They believed in their mission to contribute to the human development of the people of Papua. Secondly, because they did not regard Dutch administration after World War II as a colonial endeavour.
} 
part of the United Nations Temporary Executive Authority (UNTEA) and of the Indonesian government organization, until they retired from active service in the 1990s.

Methodologically, the individual interviews were organized in such a way that specific subjects were discussed with all interviewees (see below) while the book as a whole allows, through the temporal and spatial variation and differentiation of the individual contributions, to construct a broader and more inclusive picture of the everyday practices of the governing of New Guinea ${ }^{3}$ during a period of forty years. Particular attention is given to the period between 1961 and 1969. It stands out in the personal memory of all civil servants interviewed almost as one continuous period of destitution, political insecurity, and anger. This runs together because of the frustration over the departure of their Dutch superiors or colleagues in 1961, the ensuing insecurity and uncertainty of the short transition period under United Nations' surveillance, and especially because of the economic misery and political tensions after the inclusion as a province of the nation-state of Indonesia, culminating in the political danger and transgression of civil rights during the months before and after the implementation of the so-called Act of Free Choice in 1969.

\section{ABOUT THE TITLE OF THE BOOK}

The art of governing is rational, on the condition that it observes the nature of what is governed (Foucault 1988:149, cited in Agrawal 2005:223). Particularly in a geographically, physically, and socially little explored land like New-Guinea in the mid-twentieth century, this observation

\footnotetext{
3 The formal title of the territory was frequently changed during these four decades. From Netherlands New Guinea, it became West New-Guinea after World War II. Soekarno named it the Indonesian province of Irian Barat in December 1961, or West Irian during the short period of UN governance (1960-1962) and in international writings. In 1973 Soeharto renamed the province Irian Jaya. After the demise of President Soeharto, the name Papua came back when the new National University of Papua (UNIPA) was established in Manokwari in 2000, and A. Wahid acknowledged the name Papua in that same year, which was accepted by the Indonesian Parliament on January 7, 2002 (Kivimäki and Thorning 2002). Finally, in the political struggle with Jakarta over Special Autonomy for the province, the central government decreed in January 2003 the split into two provinces (euphemistically called pemakaran): West Papua and of Papua (Timmer 2006). Although we fully recognize that it is a historically incorrect simplification, we follow general academic practice in using the word Papua throughout the book. This is also converges with the language and the self-identification of the interviewees who spoke of Papua to indicate the country, whatever its formal political title through history.
} 
could have been the motto of the Dutch administrators who took upon themselves the daunting task of the rational or goal-oriented exploration, exploitation, and development of its natural resources and population. The Dutch administration in New Guinea was not a colonial government but a modern post-war endeavour at a development administration. Fred W. Riggs (1971:73), in a contribution to his edited volume, Frontiers of development administration defined development administration as 'organized efforts to carry out programmes or projects thought by those involved to serve development objectives'. In his view, development administration was not mere public administration but included all kinds of actions and programmes in the fields of, for example, agriculture, health, education, and infrastructure. His concept of 'prismatic society' was found very attractive and widely discussed among Papuan students at the Academy of Domestic Government (APDN) in Malang (this book, Chapter 2). Riggs was a political scientist at a time when administration and politics were treated as separate domains. While social scientists involved in development studies today would criticize such an approach for constructing itself as being outside of politics, and technocratic (Escobar 1995; Ferguson 1994; Li 2007; Mosse 2005). Yet, whatever the academic discourses used, there was an undeniable desire for human development shared by the Dutch and the Papuan civil servants in the 1950s that made the situation quite different from the pre-World War II situation.

Netherlands New Guinea was the last remaining Dutch territory after the Netherlands Indies had gained independence and became the nation-state of Indonesia. West Papua became a Dutch frontier - not to be colonized like the Netherlands Indies or for the sole purpose of establishing large-scale plantation schemes, but by being instrumental in the formation of a new nation. A frontier is indeed not a natural or indigenous category (Tsing 2005:30), yet it does create indigenous subjects. This book deals with a special category of indigenous subjects, who are not necessarily poor or marginalized, nor culturally or ethnically identifiable. Together the chapters form an account of how the Dutch governance of New Guinea - through its officials, and with the help of churches and school teachers - transformed bright young Papuan schoolboys into subjects of a new governmental system. These young men became highly instrumental in the everyday governing of often remote, under-populated, and uneducated 'wild' land, in their turn 
serving their own Papuan subjects following an external moral order of development.

The construction of a national Papuan identity was one of the Dutch government's objectives through the mission and education institutions, the Papuan Volunteers Corps and the establishment of the New Guinea Council (Chauvel 2008:41) as well as the District Councils (this book). The introduction of new agricultural crops, like coconut and cocoa, was undertaken to strengthen local production and a market economy. Large scale resource exploitation, especially oil production, however, appeared unsatisfactory or did not get off the ground before the end of Dutch government (Timmer 2006).

In the middle of the twentieth century in Indonesia, like elsewhere in ex-colonies, the desire was to enter the 'modern world' of the Europeans. In Minangkabau, for example, this led to an intense Islamic religious movement (Abdullah 1972). In Netherlands New Guinea this desire found expression in so-called cargo movements that were revivalist movements as much as 'anticipatory assimilation movements'... 'attempts at re-orientation' ... 'inspired by rational motives' ... 'becoming nationalist in nature' (Kamma 1972:3-4). The Dutch missionary Kamma (1972:225-7), who lived for ten years among the people of the Geelvink Bay, accurately describes the ambiguity of a modernization process which transforms them from being a subject in real integration into the object of a process that was steered by outsiders, the guru, the missionary, and the administrator. The Papuans' desire to be modern was found to be strongly motivated by feelings to move out of 'slavery' and to be treated as humans rather than as animals (Chauvel 2008:445) associated with the colonial history of pre-World War II when the Papuans were the territorial-political subjects of the Moluccas.

The social, cultural, economic, and political processes of modernization seriously challenged the nineteenth century scholarly dichotomies: tradition - modernity, continuity - change through new attitudes toward tradition itself and the search for a suitable basis for modernization (Abdullah 1972:179-81). A quarter of a century later in the southern part of the Bird's Head of Irian Jaya, Timmer found a similar blurring of different 'traditions of knowledge'. The Imyan people of the interior of Kabupaten Sorong in the 1990s reshaped a world that was disciplined by the church and the Soeharto regime to form an alternative order that 
put the Imyan in a central, autonomous, and powerful position (Timmer 2000:325).

The image of development as the administrators' objective of an apolitical, technical endeavour is easily created if one merely studies the official sources about Dutch intervention in New-Guinea. This book purposely moves beyond formal accounts to provide original and first-hand material about the everyday encounters of Papuan and non-Papuan civil servants, their hierarchy and collaboration, and the social interaction of the Papuan officials with the multi-ethnic urban population as well as with remote Papuan groups in the interior. Although ethnic identity formation certainly was an important element of the governing of New Guinea, it is not the focus of this volume. But it is clear from the narratives presented here that in their encounters during regular journeys into the interior, the Papuan officials paid due attention to questions about how the subjects of development came into existence and with what consequences (Agrawal 2005:225). Being Papuan and government officials, they were key to the ways in which foreign legal and democratic concepts of order and justice, of proper health and education were being translated into daily practice, and made understandable as well as understood by the local people.

\section{TRANSLATION OF FOREIGN CONCEPTS}

The word translation is applied here in its double meaning of linguistic transmission and cognitive transfer of meaning of foreign (Dutch, later Indonesian) orders, laws, regulations, and concepts into indigenous languages and societal conditions. Although translation as a social phenomenon has recently been explicitly addressed (Tsing 2005), the process of translation remains under-documented in anthropology and political studies, while even in linguistics examples of the transmission of meaning through so-called 'chain-interpreting' is seldom documented. Voorhoeve (1979:178) indicates how, during first encounters of Australian police officers with groups in the interior of southern Papua New Guinea in the 1960 s, the local interpreter had to rely on his knowledge of the language of the government and of one of the local languages, but often as much on his own talent and practical experience to perform his task of conveying the purpose and meaning of 'government'. Auditory misperception, 
perceptual misunderstanding and wilful distortion formed the bulk of misinterpretations (Voorhoeve 1979:179) that is of the message from the perspective of the sender, being the government and its representatives.

In Netherlands New Guinea in the 1950s the interpreter often was the Papuan civil servant on patrol (or turne), who often spoke Biak to a second interpreter who would then translate into a local language or dialect. Knowledge of the local conditions, the power structure and leadership practices, and forms of social organization, gender and age hierarchies were essential for a proper - and appropriate -translation of the government's orders, for example, to clean the physical surroundings of huts and settlements. This translation already implies the transmission of a foreign meaning of cleanness into a local practice, and to convey a sense of priority or hierarchy of the new governmental concept of cleanness over local values and bodily and environmental practices. The multiplicity of the translation of the term adat for the cultural and/or political purpose of strengthening ethnic identity (Tsing 2005:224-6) or the incorporation of marginal groups into the nation-state (this volume) is another example.

\section{BROKERAGE}

The volume presents several cases of the lived experiences of Papuan district heads who administered justice acting as or assisting the single judge or alleensprekende rechter, mediating between governmental legal principles based on Roman Law and local versions of adat in a process that may be rational in form, but not necessarily in its outcome (see also Schoorl 1996:16-9; Lagerberg 1996:50-2). An intriguing example is presented in Chapter 1 where the motive for the murder of the Dutch HPB was the culturally quite acceptable and legitimate revenge for the rape of the wife of the Papuan 'offender' by local police under Dutch government. He only became an offender as a subordinate of Dutch legal-civil order. The Papuan government's representative then had the task to translate the principles of the government's legal order in a way as to be able to persuade, rather than convince the man to surrender to the government. Surely, this social process of translation demands intimate knowledge of Papuan cultural practices and local adat, formal 
legal power, and personal courage together with technical language skills and eloquence.

One sometimes gets the impression from accounts of Dutch administrators that they alone brought development to Papua. While this is certainly true in a conceptual and technical sense because of the many project interventions they engineered, these very ideas and innovative practices would never have been understood and implemented if not through the translation of the indigenous tuan bestir, in turn helped by the village Papuan or Moluccan school teachers and religious leaders, and because of their high commitment and continuous interactions. They were the ones who were 'doing development' (Thomas 2000) often staying overnight in villages during their long patrols into the interior, being out of the office almost three times more often than inside.

The Papuan civil servants had several great advantages over foreign administrators, whether they were Dutch, Pakistani, Malaysian, or Indonesian. They knew and spoke at least one of the languages of the areas where they were posted, or used Biak (bahasa Biak) as the language of communication. They were the insiders-out or the outsiders-in of government intervention projects, since they were familiar with adat rules and practices concerning land ownership, marriage, and kinship, and jurisdiction. Their intimate knowledge of both the indigenous world and the Dutch administrative and legal systems made them brokers of development (Olivier de Sardan 2005; Schoorl 1996) who were indispensable to their superiors to reach out to local leaders and villagers. The interactions of the Dutch junior officials and their indigenous assistants reminds us of H.J. Friedericy's novel, De raadsman (The advisor), which depicts the interdependency of a young Dutch administrator in Makassar, South Celebes, and the wisdom of his indigenous and much more senior assistant. Although in New Guinea in the 1950s, the indigenous Papuan assistants, who had only just graduated from OSIBA, were slightly younger than the young Dutch administrators who were sent to serve in regional offices, and their situation was more one of mutual learning and understanding. Often the young men were unmarried, and outside office hours, when formal hierarchies were washed away by a collective dive in the river, a sense of equity and trust would develop which made the formal hierarchy of office work acceptable to the Papuans. 
Over the last two decades, several books have been published recounting the experiences of Dutch former civil servants who had served in New Guinea in the 1950s. In 1989, the memoirs of the former governor of Netherlands New Guinea, Van Baal (1989) appeared. Other scholars, senior government officials, journalists, and military (Schelfhout 2010) who had worked in Netherlands New Guinea also wanted to share their memories with a wider public. Schoorl (1996) has put together a set of unique personal histories of his fellow civil servants in a book entitled: Besturen in Nederlands-Nieuw-Guinea 1945-1962. The volume documents a wide variety of Dutch narratives that together provide insight into how formal governmental structures and the personal initiatives of these Dutch civil servants created a social, economic, and political environment which enabled their Papuan staff to professionalize, and the Papuan population to develop into a modern nation. More recently, the international political history of West New Guinea has been the subject of two other publications. Vlasblom (2004), who had for many years been a Dutch journalist in Indonesia, went to stay several months in Jayapura to write his book on the history of Papua. In 2005, the book by Drooglever appeared on the so-called Act of Free Choice of 1969 that determined Papua's integration into the Indonesian nation-state. In the stories of the Dutch civil servants, Papuans do of course appear, and Vlasblom interviewed former Papuan leaders on their views of historical events. But we are told very little about the ordinary Papuan civil servants who did not have a high political profile, and their structural positions, experiences, hopes, and frustrations in the actual implementation of development through their everyday practices, and in their own words (Visser and Marey 2008).

Governing Nere-Guinea aims to fill this gap in our historical knowledge and understanding of a unique era in the governance of New Guinea/ Papua as it was carried out and lived by the indigenous civil servants at the time. It comprises a unique series of narratives by former Papuan civil servants who were selected to enroll in a special school - OSIBA or the School for Indigenous Administrators - which was between 1950 and 1962 senior high school plus administrative school to be taught to govern their land, first as assistants, later as sub-district heads, and finally as district heads or hoofd plaatselijk bestuur (HPB). In the various chapters 
they describe their everyday lives as civil servants, first in co-operation with the Dutch, then with the UN interim managers during the nine months of the UNTEA period (1962-1963), and subsequently within the Indonesian government administration until the early 1990s, when most of them retired from active government service.

\section{METHODOLOGY}

The idea to document the everyday practices and experiences of Papuan administrators started on 20 May 1998 when Marey and Visser met in Leiden on the occasion of a public lecture at IIAS. The book by Schoorl on the contribution of the Dutch administrators had been published two years earlier. But there was still scant documentation about the role and contribution of the Papuan administrators. From our subsequent discussions at the Netherlands Institute of History (ING) in The Hague it appeared that there were considerable gaps in our knowledge about the educational background, selection process, contacts during office time, and out of office interactions involving the Dutch, Papuan, and Indonesian members of staff, the regular tasks, and activities of the Papuan staff, as well as their contacts with the population at the administrative posts in the towns, but even more so, at the posts in the interior. We decided that we would try to fill the gaps in our knowledge of that unique period in the history of development administration in Netherlands New Guinea by systematically including the following topics in the interviews:

- selection and education at the School for Indigenous Administrators (OSIBA);

- the hierarchy and social relationships in the office and after office hours among the Papuan, Dutch, and Indonesian civil servants;

- their first and subsequent postings;

- communications and contacts with the local population;

- experiences of and attitudes towards adat rights et cetera.

Another aspect we wanted to know more about was the origin and organization of democracy in New Guinea through the construction of institutional organizations, especially the Streekraden (Regional Councils) 
in the late 1950s. In the narratives of this book we get glimpses of how modern notions of democracy were originally negotiated and embedded in indigenous or adat notions of power and representation in the public arena, through the establishment of the councils which were the precursors to the modern Dewan Perwakilan Rakyat Daerah (DPRD, Regional Council of People's Representatives).

The turbulent decade of the 1960s is covered by:

- accounts of the civil servants on their positions;

- experiences and actions during the transition period under UN custody from 1 October 1962 until 1 May 1963;

- the turbulent years from 1962 to 1969 and, finally,

- experiences during the preparations and enactment of the so-called Act of Free Choice of 1969.

\author{
COMPARISON BETWEEN DUTCH (1950-1962) AND \\ INDONESIAN (1963-1990) ADMINISTRATIONS
}

Apart from an oral history of the years 1950 to 1962 we wanted to gain insight into the process of transformation from a Dutch administrative order, through the short UN intervention, into an Indonesian government administration. What changes took place in the social and hierarchical relationships between staff? Who did the reporting and what issues were reported? Who made decisions about what, and how did the knowledge exchange between governmental scales and sector departments in the Indonesian system impact on the development administration, as compared to the more integrated approach of the 1950s? Was there a change in attitude among the civil servants themselves?

The fact that our interviews took place in 1999 and 2000, that is, after the demise of the Soeharto regime in 1998 during the short wave of optimism during reformasi, made it easier to reflect upon both - now historical -administrative practices of the two periods of 1950-1962 and 1963-1998. Not all of the authors felt at ease to do so, and we may sometimes recognize their reservations in the elusiveness of the text. But most interviewees felt relieved and pleased to be challenged by our questions and our demand for reflection. The most striking differences mentioned related to governance practices in the different social, economic, 
and political contexts. In the 1950s, the civil servants 'made do' with whatever capitals were available locally: manpower, local construction materials, long patrols into the hinterland by boat and on foot; making use of village teachers and missionaries to translate their requests and orders into the local dialects. They mediated between adat and government, and received comments and advice as positive feedback on their reports which motivated them to improve their performance. The style of governance was seen as more personal as opposed to the formalistic and impersonal governance style and attitude of the Orde Baru period. During the Soeharto government, the Papuan administrators depended on orders and the sending of material and financial means from Jayapura and Jakarta; reporting to their superiors had become a formality which provided little realistic insight into the local conditions since the administrators seldom left their offices, and they did not receive positive (if any) feedback on their efforts. The Indonesian language was the language of the State, no effort was undertaken to translate new concepts and laws, and it was not seen as problematic if the Papuan population did not understand them.

When the Indonesian original of this volume appeared in 2008, it sold well and clearly responded to a demand. Its lively accounts and many interesting examples were welcomed by the district heads or bupati of the recently decentralized two provinces of Papua and West Papua. The personal and sometimes highly emotional accounts containing a wealth of information about the institutional organization of government services from the 1950s, through the highly volatile 1960s, and into the Indonesian New Order regime, appear to have become part of the present-day discourse on development (personal information, January 2009 and November 2011). Moreover, the surviving contributors to this volume, who had been marginalized politically for almost four decades as napol/tapol had recently (re)gained public acknowledgement as members of the special committees of the Papuan Congress, and were often contacted by today's government officials and university lecturers for explanation and comments on the book (personal information, 2009). Their narratives provided first-hand information about the necessary integration of formal governmental structures, rules, and norms and the dominant social and cultural institutions and organizational practices of adat. Many subjects discussed evidently strike a familiar cord, like the cases of competing claims to newly introduced cash crops on adat 
land, local agricultural practices and their cultural valuation conflicting with foreign ideas about modern land and forest uses, the spatial arrangements of house and village construction, and a lot more, and the considerations and negotiations in order to decide which elements could be integrated, and which were conflictive with the demands of modernization and development. Although many of the particularities of the cases narrated may indeed be things of the past, the underlying issues like the political power of kinship relationships, adat rights, claims to land and forest resources, and the public distrust toward 'government' remain important issues today.

There are, however, major structural and organizational differences between the two administrative orders and their social, economic, and political contexts. A first difference surfacing from this volume is that the sector division of government departments had not yet been introduced; it was introduced with the Indonesian government structure in the 1960s. The civil servants of the 1950s - who were invariably addressed as: Tuan Bestir, or Mr. Administrator - were truly multifunctional. They had administrative, financial, and political responsibilities to keep peace and order; they administered an integrative form of justice; and they advised on health, education, agriculture, and infrastructure development to local leaders, on the one hand, and to their foreign administrative superiors, on the other hand. As a result, their decision making capacity was of a more integrative, trans-sector character in, for example, the spatial development of houses, infrastructure, and education and health facilities. Although in the Dutch public administration system in The Hague, sector divisions between departments of forestry, agriculture and fisheries, health, education, public works, and so on, did formally exist, in the governing of New Guinea they blended into the position of the sub-district or district head who was often the only man on the post, particularly in the interior, who was responsible toward his superiors in Hollandia or Jakarta.

A second important difference relates to professional attitude. The picture emerging from the narratives of the civil servants in the 1950s and early 1960 s is that they were disciplined through their schooling, taught to be 'servants of the people' (see the second footnote of this introduction) and that they carried out the orders from their superior, but with sufficient room to manoeuvre. Most importantly, they were allowed to take initiatives, and were praised for it. They had to write monthly reports to their 
superiors about their observations and encounters during their patrols into the interior; their superiors, in turn, wrote reports to their superiors, climbing the bureaucracy up to the governor. It clearly emerges from this volume that there was an element of professional collaboration and education between the Dutch and the Papuan administrators because of the feedback given by superiors by way of comments for improvement in the margin of the reports which were sent back to the authors all the way down the hierarchy. The Papuan civil servants were thus made to feel proud of their work. During a recent visit to Jayapura government officials, indigenous Papuan and others, remarked upon this major difference with today's governmental attitude and organizational practice. They commented upon the fact that the initial hope for new initiatives created by the formalization of the Special Autonomy (OTSUS) in 2001, to be able to address problems and search for solutions that would apply to the local conditions, in other words, to be proud of their contribution to the development of Papua, was now lost (semangatnya hilang). The resulting lack of initiative at lower administrative levels resembles the frustration described in the Geelvink Bay in the first half of the twentieth century described by Kamma (1972:227). But there seems to be a serious inversion of the situation due to the fact that the leaders now do not come from outside, but they are members of a new Papuan elite who somehow are unable to convey the image that they are servants of the people (hamba rakyat) in the sense of the OSIBA education of 1950-1962.

The biggest changes were felt after 1962. First, the new sector division and the lack of a central reporting resulted in a general lack of systematic and inter-sector accounting of activities. The reports that were made were not systematic any more, as each department, whether Health or Education, developed its own style. Secondly, the status and income of the civil servants was changed immediately upon the transfer of power. They lost their secure position as government officials and became temporary officials (pegawai sementara) in the Indonesian administrative system, with a concomitant reduction in salary. Thirdly, the monetary unit was changed from Guilder into Irian Barat Rp (IBRP). Because of the value difference, Indonesians who came to fulfill government services in West Irian had an economic advantage over local people (Visser 2008:19). The accounts in this book also help to broaden our view on issues such as the rise of OPM. Usually described as a guerrilla movement (Osborne 1985; Djopari 1993), we now learn (Chapters 8, 10, 16) 
that the scarcity of food, provisions in the Chinese stores being emptied by the incoming Indonesians, and general impoverishment from 1963 onwards triggered the first protests and political movement.

Another issue, raised incidentally, is that of unequal development opportunities (Chapter 8). In the 1950s the Papuan pupils were selected by their heads of school on the basis of their intelligence and attitude, not on the basis of a political economy of power, to do the entrance examination of the School for Indigenous Administrators (OSIBA). Mostly they were children of Papuan village heads (korano) or adat leaders (ondoafi), and many of them from the north coast. Professionalism of a future generation of Papuan administrators was the objective of the OSIBA, hence non-Papuans were not admitted. They received teachings on a broad range of subjects. Ethnology was one of them, and the young administrators were trained to respect cultural difference and to use it as an asset, not as a threat, to development. In the 1950s there was still a disjunction between state and society (Brown 2007). This was the case of an emergent state rather than of a failed state, as there was still a very thin connection between society and the newly developing institutions of the state, particularly in the interior. Yet, when the state did come in strongly after 1963, there was a growing inequity between Papuans and Indonesians to access education and training and to the chances to access government positions (Chapter 14; see also Timmer 2008).

The alumni of the OSIBA had in many places become the representatives of these new democratic institutions, like the Regional Councils, who were given the task to engage the people in a new political experiment already at the end of the 1950s, that of democratic participation (Chapters 9, 10, 15, 16, 17). Of course notions of democracy already existed in Papuan society (Chapter 14) but this referred to the culture of reciprocity and inter-family co-operation. The European notion of democracy was introduced in the second half of the 1950s with the establishment of the Regional Councils, thus predating the establishment of the New Guinea Council. The Regional Councils were valued as democratic institutions for three reasons. Firstly, the election process. The civil servants themselves did not vote; they were instrumental in visiting the villages to register the names of those men who were 18 or more and heads of a family, and who had been elected by the villagers to become their representatives. These representatives then elected the members of the Regional Council. A photo of each candidate was posted at public 
places, and the election procedure was announced on the radio. This direct representation through an administrative election was seen as more democratic because of the accountability of the members of the Councils to the people in the cities and villages, than the Indonesian party system that was applied to the membership of the later DPRD.

Secondly came the tasks and functioning of the Council. It was highly appreciated that the members of the Council could take development initiatives themselves when they felt their action responded to a need of the people. It was seen as 'autonomous development with little funding' (Chapter 15) which was contrasted with the more recent attitude to wait for the directives of 'projects' and their funding. Of course, the initiatives in the 1950s were also in a sense 'directed' by the demands for development, like bringing people down from the mountains to establish villages, to teach them how to build houses using local materials, etc. Thirdly, the regional councils acted as a governmental development organization who actually owned property and equipment, like rollers and trucks (Chapter 10), and they would acquire land for plantations which was levelled with the equipment that could be leased from the treasurer of the Council.

Democracy in the modern sense of political democracy was severely challenged throughout the 1960s. Although the Regional Councils chaired by the district heads continued to function under UNTEA custody, the administration had to learn to communicate in English, which slowed down the administrative process and led to misunderstandings. The Regional Councils and the New Guinea Council were dissolved from 1963-1964 onwards. Papuans mostly rejected the Indonesian system of 'democracy by deliberative consensus' (Chapter 2). The 1960s, especially the political engineering of the so-called Act of free Choice of 1969 stands out in the collective memory of the Papuan people, and has well been documented (Drooglever 2005; Meijer 1994; Osborne 1985; Vlasblom 2004). The accounts in this volume add another perspective to these sources: the first-hand information about the famine of the early 1960s, the economic and societal impact of the Indonesian interventions since 1961, culminating in the unlawful dismissal, dispatching, or incarceration of Papuans while in government service in 1968-69 in order to politically exclude them from participation in the voting during the socalled Act of Free Choice (Chapters 5, 6, 7). Others, who were allowed to vote, were given no choice (Chapter 16), while those government officials who did participate were subsequently labelled as political pris- 
oners, which has influenced their subsequent career paths in Indonesian government service (Chapter 2).

The material property of the Regional Councils disappeared. But, more importantly, the administrative system of popular representation was overruled in favour of a party-based election of representatives. After 1963 the Indonesian government in West Irian formed Regional Councils of People's Representatives (DPRD). But the DPRDs were politically marginalized in the preparations for the Act of Free Choice which was given in the hands of Dewan-dewan Pepera (Chapter 9) or special consultative councils (Drooglever 2009:708, 758).

\section{DOCUMENTING ORAL HISTORY}

This book is an oral history account. All chapters are based on verbatim transcripts of interviews held in 1999 and 2000 in Jayapura and Biak. We interviewed the retired civil servants twice or three times and recorded their narratives with the help of a Sony mini-CD recorder ${ }^{4}$ that was small enough not to disturb the speaker, and yet able to record their speech clearly enough to allow a verbatim transcription onto a word programme. It turned out that the men were eager to have their stories recorded. Although they were well trained to write administrative reports, only two of them insisted on checking their interviews and writing a more detailed account on the basis of their interviews of 1999 (the story about HPB Hielkemeijer in Chapter 1, and the first part of Chapter 3).

The interviews were loosely structured and open-ended in order to provide sufficient focus for the publication of a volume on their lives and experiences during some forty years of government service. ${ }^{5}$ The advantage was that we could ask the same set of questions to all contributors

4 On 3 March 2010 all the original mini CD-Rom's were donated to the Royal Netherlands Institute of Southeast Asian and Caribbean Studies (KITLV) in Leiden, the Netherlands, where they are accessible to the children and relatives of the authors, as well as to scientists and other interested people across the globe (www.kitlv.nl).

5 The chapters more or less follow the sequence of the original interview(s). In some cases, the interviews of 1999 by Visser were checked during a second interview with the same persons in 2000 (Chapters $1,2,3,6,7,8,11,12$ ). Unfortunately, this proved impossible in the cases of persons who had died or moved away from Jayapura and Biak, and could not be pursued under the political conditions of 2000 and funding constraints. Other chapters are the result of a single interview by Marey in 2000 (Chapters $4,9,10,13,14,15)$, or of a single interview Visser and Marey did together (Chapters 5 and 16). Marey himself was not interviewed but wrote Chapter 17 as the final chapter. 
to this volume, while still following their line of thought and associative style of narration, in order to obtain a comparable, yet highly diverse set of data that together would provide a more coherent historical picture than would be provided had we collected just a series of idiosyncratic memoirs. The major subjects of the interviews were given only at the introduction of the first interview session together with an explanation of our intention to publish them in Indonesian and, possibly later, in English. The resulting recordings were all but pre-determined, structured interviews, and the valuable quality of an oral history account was certainly retained, as in most cases the speakers became highly involved in sharing their experiences, remembering how they travelled, who they encountered, what fun and frustrations they had known. We regard the ownership of these original narratives as remaining with the civil servants and their widows. ${ }^{6}$ Most interviews were conducted and recorded during one-and-a-half to three hour sessions. Papuans are excellent storytellers and they like a good laugh, so their narratives are full of engaging events. The oral history character of the narratives is most evidently present in those interviews when the narrator reconstructs a particular journey that he made (Chapters 1, 3, and 17). As often in story telling or recounting myths, it is not the final destination that matters but the journey itself, the very repetition of the narrated action being an indication of its relevance as much as a mnemonic device. Also, since social relationships and geographical knowledge can be of life-saving significance, personal names of people encountered and places passed by are recounted in great detail. The narratives clearly show these characteristics.

Who then were the contributors to this volume, and how did we access them? The selection was made from among alumni of OSIBA on the basis of the collegial network Marey had kept up with through the years, with the help of his friend Amos Yap in Jayapura. On 8 February 1999 we sent letters around to Irian Jaya/Papua to invite them to participate in this project of documenting the governance history of that unique period of 1950-1962. Unfortunately, several of the addressees

\footnotetext{
6 Between 2000 and Visser's visit to Jayapura in January 2009 to distribute copies of the Indonesian publication of Bakti pamong praja Papua (Visser and Marey 2008), seven contributors had already died: Ismael Bauw, Joel Boray, Florenz Imbiri, Dorus Rumbiak, Dirk Urus, and Alex Wamafma. Dolf Faidiban died only a week before Visser's arrival. Fortunately, the other contributors all lived to see their histories published. In May 2010, Trajanus Boekorsjom died, and Arnold Mampioper died in November 2011. In October 2011 the royalties received over 2009-2011 from the Indonesian publisher were divided among the widows who could be met in Jayapura.
} 
were already deceased. After receiving positive responses from 16 former civil servants, we proceeded. In 1999 Visser happened to be in southwest Irian Jaya, in Teminabuan, for research together with PhD students of the Irian Jaya Research Project (ISIR) ${ }^{7}$ and she travelled on to Jayapura to have the first meetings with eight potential contributors, who spontaneously accepted to be interviewed. The next year, 2000, despite considerable unrest, we wanted very much to continue the work. Marey and his son were then visiting relatives in Irian Jaya, and he managed to interview several of his old friends during that visit. Meanwhile, Visser was invited as a visiting scholar by the Rector of Universitas Cenderawasih (Uncen) in Jayapura, F. Wospakrik, and the head of the research division, J. Mansoben. Besides giving some lectures at Uncen, she was able to have a series of interviews with the retired civil servants she interviewed in 1999 as well as an interview with the former governor of Irian Jaya, B. Suebu, who was at that time the Indonesian Ambassador to Mexico, and happened to visit Uncen. Evidently, Suebu was not an OSIBA alumnus, but we wanted to show the parallels between the perspectives on village development projects of the 1950s and Suebu's villagization project (Chapter 11) during his first period as governor of Irian Jaya (1988, 1993).

The transcription of the oral texts, spoken in Papuan Malay, into Word documents took a long time. Most interviewees spoke modern Indonesian, but several of them spoke Papuan Malay, often mixed with Dutch words, and the particularities of pronunciation, stress, and use of specific terms or meanings are not easily heard and understood by somebody who is not familiar with that dialect. Marey of course speaks it fluently, while Visser, through long-term field research in these areas, is quite familiar with speaking and hearing Papuan Malay, which is close to Moluccan Malay. Between 2001 and 2005 and with the help of the Papuan linguist Voorhoeve, all interviews were transmitted to Word documents. Subsequently, P. Sutikno and especially F. Athaboe edited the Indonesian texts in such a way that an Indonesian-speaking international public would understand them, but without sacrificing the Papuan

\footnotetext{
7 Irian Jaya Studies: a Programme for Interdisciplinary Research (ISIR) was initiated by the International Institute of Asian Studies (IIAS, Leiden, W.A.L. Stokhof) and carried out in collaboration with LIPI, Jakarta in the Birds Head peninsula of Irian Jaya between 1993 and 2000. Research was carried out in the fields of anthropology, archaeology, botany, demography, development administration, ethnobotany, geology, history, and linguistics. See Miedema, Odé and Dam 1998.
} 
and time-specific flavour of the narratives. It was decided that first an Indonesian language version of the book would be published ${ }^{8}$ because of its societal relevance. Unfortunately, the risk of political or personal harm to the interviewees or their families was not unthinkable around 2005, so publication was postponed. Preparations for the Indonesian publication started in December 2007 with a meeting, together with J. Erkelens in Jakarta, with Kompas which resulted in the publication of the book in Indonesia in November 2008, under the title Bakti pamong praja Papua di era transisi kekuasaan Belanda ke Indonesia. The map was made by Hans Borkent. ${ }^{9}$ The current book is an English translation ${ }^{10}$ of the Indonesian chapters by Sherry Kasman Entus in close cooperation with Visser, and with a new Introduction. The volume reveals for the first time to an English readership the dynamic history of the governance and modern development of today's provinces of Papua and West Papua. It also does so consistently from the perspective of the indigenous Papuan civil servants who represented the governmental institutions of their time, and it is done in a way to allow them central stage by preserving as much as possible their uses of language, narrative rhythm, and style.

\footnotetext{
8 A small subsidy was provided by the Dutch Ministry of Foreign Affairs through the Institute of Netherlands History.

9 The map was made for the Indonesian publication in 2008. Sadly, Hans died in June 2011, and he could not adapt his map to the English publication. In honour of his work and friendship we include the map of 2008 .

10 A small subsidy was provided by Wageningen University, Chair group of Rural Development Sociology.
} 